\title{
Volatile Methyl Siloxanes as Potential Hazardous Air Pollutants
}

\author{
Kazimierz Gaj*, Anna Pakuluk \\ Faculty of Environmental Engineering, Wroclaw University of Technology, \\ Wybrzeże Wyspiańskiego 27, 50-370 Wroclaw, Poland
}

Received: 10 November 2014

Accepted: 3 December 2014

\begin{abstract}
Due to the more and more common use of siloxanes in consumer products and various industries, there has been an increase of their concentration in biogases produced from sewage sludge and municipal waste and, consequently, in the soil, water, and air. This paper presents sources and mechanisms of siloxane migration to the environment, characterizes types and products of their transformations in the atmospheric air and during the combustion of biogas, assesses hazards posed to the atmospheric air, and presents the results of siloxane concentration measurements in biogases and the atmospheric air. It draws attention to the new problems that have emerged in toxicology and atmosphere protection, outlines directions for necessary research, proposes ways to reduce emissions of volatile methyl siloxanes (VMS), and suggests the introduction of relevant legislation.
\end{abstract}

Keywords: cosmetic products, waste, biogas, silicone compounds, toxicity

\section{Introduction}

Siloxanes are substrates of silicone polymers commonly used in many industries and household products. They are extensively used in cosmetic products as an ingredient of shampoos, deodorants, aerosols, and various types of treatments and colorings. They are also applied for the production of lubricants, adhesives, paints and solvents, foams (e.g. polyurethane), detergents, fabric softeners and protectors, seals, and elastomers. In medicine they have been used, e.g., in manufacturing of prostheses, implants, catheters, and blood transport equipment. They are increasingly replacing chlorofluorocarbons which, as they deplete the ozone layer and intensify the greenhouse effect, are gradually phased out. Due to the rising industrial consumption of silicones, they were included by the OECD in the list of high production volume chemicals [1]. In 2006 the European Commission issued Decision No.

*e-mail: kazimierz.gaj@pwr.edu.pl 
<smiles>C[Si](C)(C)O[Si](C)(C)O[Si](C)(C)C</smiles>

a) Linear VMS

$\mathrm{n}=0$ - hexamethyldisiloxane (L2)

$\mathrm{n}=1-$ octamethyltrisiloxane (L3)

$\mathrm{n}=2$ - decamethyltetrasiloxane (L4)

$\mathrm{n}=3$ - dodecamethylpentasiloxane (L5)

Fig. 1. Primary structures of siloxanes.

to $6 \mathrm{Si}$ atoms. Most of them have low chemical reactivity, high vapor pressure, and low surface tension. They are poorly soluble in water and easily so in non-polar solvents. Particular characteristics of siloxane polymers are resistance to oxidation and UV radiation, small variation of physical properties with temperature, and extreme polysiloxane chain flexibility, which affects their low viscosity. The overview of the main physical and chemical properties of VMS and their structure have been presented in [2]. The above-described wide use of siloxanes results both from their universal properties and their commonly perceived environmental neutrality. This view, however, raises more and more serious controversy. Recent reports indicate their potential toxicity, carcinogenicity and bioaccumulation capability, especially as they are relatively persistent. Their impact on living organisms, their migration routes in the environment and mechanisms of decline in the atmospheric air are poorly known. Rapid development of renewable energy sources, which include siloxane-containing biogas, also contributes to increasing pollution of the environment with VMS.

\section{Mechanisms and Conditions of VMS Migration to Biogas and Atmospheric Air}

In WWTPs and landfills siloxane polymers, in particular polydimethylsiloxane (PDMS), are subject to partial or complete hydrolytic depolymerization, transforming into VMS, which are released into the air or adsorbed on sludge floccules at WWTPs and on the surface of landfill waste. This applies especially to water-insoluble VMS of a high molecular weight, i.e. D4 and D5. As a result of the fermentative decomposition of the substratum and the elevated temperature, they are released into the biogas and flow with it to the air or to the combustion installation. They are not decomposed in a conventional biological wastewater treatment process [3]. Silicon compounds with better water solubility and low vapor pressure (e.g. L3, silanes,

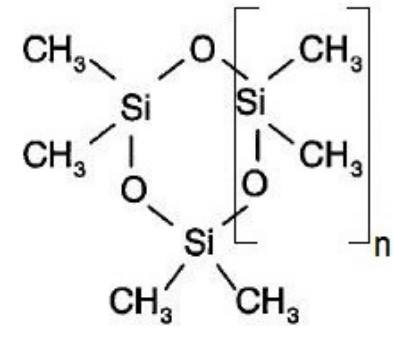

b) Cyclic VMS

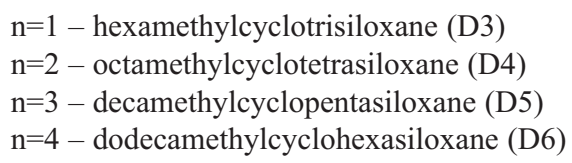

$\mathrm{n}=4-$ dodecamethylcyclohexasiloxane (D6)

silanols) get into the receivers of treated sewage or landfill leachate, hence their presence both in biogas and in the air is insignificant. Smaller VMS molecules with high vapor pressure (D3, L2) are released into the air either during wastewater treatment or earlier i.e., in the sewage system. The molecules with the lowest vapor pressure and the highest molecular weight (D6, L5) mostly remain permanently bonded with post-fermentation sediments. The same applies to the previously mentioned PDMS polymers. D5 constitutes more than $90 \%$ of the siloxane compounds included in municipal wastewater. The total efficiency of its removal during wastewater treatment is about $97 \%$ (including volatilization during aeration, and bonding with the sediment), with $20-50 \%$ of the remaining D5 penetrating into biogas [4]. The amount of VMS released from landfills depends on their content in the waste, deposition time and temperature of the bed. Due to the continuous increase in the use of siloxane polymers and high volatility of the products of their hydrolysis, emissions of VMS from newer landfills are greater. Higher siloxane concentrations may be expected near landfills in large urban areas [5].

During biogas combustion, VMS partially precipitate in the form of silica and silicate deposits on the inner surfaces of engine chambers, cylinder heads, nozzles, valves, spark plugs, exhaust gas catalysts, etc. They also get to the engine oil, worsening its lubricating properties. This results in a decrease in the efficiency and availability of equipment and an increase in air pollutant emissions, including fine $(<100$ $\mathrm{nm})$ toxic dust containing silica. However, it is estimated [6] that only $0.5-1 \%$ of siloxane content in biogas converts to $\mathrm{SiO}_{2}$, while the rest is emitted into the air with exhaust gases.

Waste siloxanes D4 and D5 used in consumer products are mostly directly emitted to the atmosphere. Only a few percent reach WWTPs [7]. This has also been confirmed by Allen et al. [8], who have estimated that $92 \%$ of the D4 used in personal care products evaporates directly into the atmosphere. 
Table 1. VMS concentrations in the air - the results of the existing studies [19-25].

\begin{tabular}{|c|c|c|c|c|c|c|c|c|}
\hline \multirow{2}{*}{ Location } & \multicolumn{8}{|c|}{ Concentration $\left[\mu \mathrm{g} / \mathrm{m}^{3}\right]$} \\
\hline & D3 & D4 & D5 & D6 & L2 & L3 & L4 & L5 \\
\hline WWTP in Ontario, Canada & $0.002 \div 0.27$ & $0.241 \div 2.06$ & $0.812 \div 5.38$ & $0.03 \div 0.25$ & - & $\begin{array}{c}0.001 \div \\
0.002\end{array}$ & $\begin{array}{c}0.002 \div \\
0.006\end{array}$ & $\begin{array}{c}0.001 \div \\
0.004\end{array}$ \\
\hline $\begin{array}{l}\text { Landfill in Ontario - } \\
\text { upwind side, Canada }\end{array}$ & $0.11 \div 0.18$ & $0.47 \div 1.84$ & $1.59 \div 4.82$ & $0.08 \div 0.19$ & - & $\begin{array}{c}0.0056 \div \\
0.0061\end{array}$ & $\begin{array}{c}0.022 \div \\
0.024\end{array}$ & $\begin{array}{c}0.0028 \div \\
0.0032\end{array}$ \\
\hline Whistler, Canada & 0.117 & 0.045 & 0.06 & 0.0015 & - & 0.00002 & 0.00007 & 0.00004 \\
\hline Paris, France & 0.03 & 0.05 & 0.28 & 0.053 & - & 0.00003 & 0.00006 & 0.00012 \\
\hline Kosetice, Czech Republic & 0.025 & 0.009 & 0.08 & 0.0017 & - & - & - & - \\
\hline Råö, Sweden & - & $0.035 \div 0.300$ & $0.009 \div 0.17$ & $0.011 \div 0.077$ & $\leq 0.073$ & $<0.006$ & $<0.006$ & $<0.006$ \\
\hline Nordic countries & - & $0.08 \div 4.00$ & $0.05 \div 19.00$ & $0.02 \div 2.10$ & - & - & - & - \\
\hline Chicago - downtown, USA & - & $0.02 \div 0.19$ & $0.11 \div 1.1$ & $\leq 0.05$ & - & - & - & - \\
\hline $\begin{array}{l}\text { Sweden - rural site (200 } \\
\text { km west of Stockholm) }\end{array}$ & - & - & $\begin{array}{c}0.0003 \div \\
0.009\end{array}$ & - & - & - & - & - \\
\hline Zürich - centre, Switzerland & & - & $0.10 \div 0.65$ & $0.01 \div 0.08$ & - & - & - & - \\
\hline
\end{tabular}

\section{VMS Concentrations - Analysis of the Existing Measurement Data}

Typical VMS concentrations in biogases produced at WWTPs and landfills range from a few to several tens of $\mathrm{mg} / \mathrm{m}^{3}$ [9-15]. In general, higher concentrations are found in the biogas from sewage sludge, which may be due to a higher fermentation temperature. This gas is dominated by less volatile siloxanes - D5 (48-76\%) and D4 (21-45\%) which account for more than $90 \%$ of the total VMS. This has been confirmed by the authors of the research done at a Polish WWTP with a capacity of about $100,000 \mathrm{~m}^{3} / \mathrm{d}$ where biogas is produced from sewage sludge [2]. Before combustion in the gas-powered piston engines that drive electricity generators (Jenbacher, $3 \times 600 \mathrm{~kW}_{\mathrm{e}}$ ), the biogas produced in the mesophilic fermentation process is treated by condensation drying and desulfurized using activated carbon impregnated with potassium iodide. Simultaneously with desulfurization, VMS are partially adsorbed. Biogas samples were collected by absorption in methanol and a GC-MS analysis was performed. A standard set of 8 VMS (Fig. 1) was analyzed of which only D4 (concentrations: $1.2-2.6 \mathrm{mg} / \mathrm{m}^{3}$ in the raw gas and $1.0 \mathrm{mg} / \mathrm{m}^{3}$ after adsorption) and D5 (respectively: $6.9-26.1 \mathrm{mg} / \mathrm{m}^{3}$ and $1.0 \mathrm{mg} / \mathrm{m}^{3}$ ) were detected. The predominant share of D5 in this type of biogas confirms earlier reports in the literature. It is also worth paying attention to the varying efficiency of D4 and D5 removal, which may confirm the thesis about displacing the previously adsorbed D4 by D5 and/or VOCs present in the biogas.

In the case of landfill biogas, the shares of individual VMS are different. Dominant are those with higher vapor pressure and better water solubility - L2 (28-40\%), D4 (24$72 \%)$, D5 (3-13\%), and D3 (0-7\%) [9, 16, 17].

Compared to the concentrations in biogas, siloxane concentrations in the atmospheric air are smaller by several orders. The analysis of published measurement data [18] has shown that the largest concentrations of D4, D5, and D6 are at WWTPs near aeration chambers $(0.1,2-3,0.04$ $\mu \mathrm{g} / \mathrm{m}^{3}$, respectively). Global distribution of VMS concentrations was studied by Genualdi et al. [19] in 20 points located in the U.S.A., Europe, and the Arctic. They proved the interrelatedness of D3-D4 and D5-D6 concentrations resulting from different origins of these pairs of siloxanes. The highest concentrations of D3 and D4 were reported on the west coast of North America and the uppermost measurement points, which may indicate their influx from the Pacific. In contrast, D5 and D6 reached the highest concentrations in urban areas, which could result from increased use of personal care products (D5 is the most commonly used siloxane in such products) and greater number of municipal and industrial VMS sources. In non-urban areas and the Arctic (defined as background points), D3 and D4 were dominant (up to $0.044 \mu \mathrm{g} / \mathrm{m}^{3}$ - in Ucluelet, Canada), whereas in the cities D5 and D6 prevailed (up to $0.28 \mu \mathrm{g} / \mathrm{m}^{3}$ in Paris). According to the research on the VMS content in the air carried out in different locations in the Nordic countries [20], total concentrations of D4, D5, and D6 most often ranged from 0.1 to $5.0 \mu \mathrm{g} / \mathrm{m}^{3}$ (except for the samples from WWTPs, which reached up to about $20 \mu \mathrm{g} / \mathrm{m}^{3}$ ). In the urban air, concentrations of individual VMS ranged from 0.1 to $2 \mu \mathrm{g} / \mathrm{m}^{3}$. Variation ranges of VMS immission measurements published so far for different locations are summarized in Table 1.

\section{Decline and Transformations of VMS in the Environment}

Siloxanes can be removed from the atmosphere by wet and dry deposition and chemical transformations. In practice, both deposition mechanisms - due to poor VMS 
water solubility and high vapor pressure - are practically negligible. The main siloxane transformations in the air include oxidation reactions: photochemical, with $\mathrm{OH}$ and $\mathrm{NO}_{3}$ radicals, and with ozone. For the photolysis to occur, the decomposed substance should have the ability to absorb radiation in the range of 290-800 $\mathrm{nm}$. Previous studies have shown, however, that VMS do not absorb radiation longer than $190 \mathrm{~nm}$ [26]. There was also no observed influence of the concentration of $\mathrm{O}_{3}$ and $\mathrm{NO}_{3}$ radicals on the decline of VMS levels in the air. On the other hand, they react with $\mathrm{OH}$ radicals, which are formed in the troposphere mainly by $\mathrm{O}_{3}$ photolysis (at $290-320 \mathrm{~nm}$ radiation) and reaction of atomic oxygen with $\mathrm{H}_{2} \mathrm{O}$. VMS lifetime calculations for the three above-mentioned oxidation mechanisms led to the following results [26]: 150 days in the case of $\mathrm{NO}_{3}, 1.5$ year - for $\mathrm{O}_{3}$, and 8 (D5) to 23 (D3) days for $\mathrm{OH}$. According to [27], the lifetime of VMS resulting from the reaction with $\mathrm{OH}$ radicals ranges from 10 days in the case of D5 to 30 days in the case of D3. Similar values were obtained in model tests [28] for D4 and D5, respectively: 11.5 and 7.5 days, assuming the average concentration of $\mathrm{OH}$ radicals representative of the north-central latitude. D6 reacts with $\mathrm{OH}$ radicals the fastest, with 1.6 days as the calculated time of half-decline [29]. Hobson et al. [26] have found VMS lifetime inversely proportional to the $\mathrm{OH}$ radicals concentration in the troposphere and seasonal variations in VMS concentrations as a result of UV radiation variability, which affects the formation of $\mathrm{OH}$ radicals. Due to the relatively long residence time of VMS in the troposphere, they are included in the group of substances with potential for longrange atmospheric transport [30]. According to the model tests [18], the range of this transport can exceed 5,000 km.

The daily variability of VMS concentrations was tested by Yucuis et al. [23] proving its clear correlation with the height of the mixing layer, especially in the case of D5. The reason for such a relationship, in addition to the obvious effect of nocturnal temperature inversions, could be daily fluctuations in the concentrations of $\mathrm{OH}$ radicals, associated with UV radiation variability. Carrying out measurements in cities with different population densities, they found yet another regularity. The greater, the D5/D4 concentration ratio, the higher the population density, and it ranged from 4.5 for Chicago to 2.1 for West Branch in the USA. This may result from a lifetime of D4 longer than of D5, making the share of D4 increase in locations more distant from the emission sources, i.e. large population centers.

The products of siloxane oxidation with $\mathrm{OH}$ radicals are mainly silanols, further removed from the atmosphere - as compounds better soluble in water and with lower vapor pressure - by wet deposition. They can also condense on the particles of suspended dust and be subject to dry deposition. As a result of the above-mentioned processes, they get into the soil where they undergo slow degradation. So far, no biological mechanisms have been detected that would lead to the formation of bonds between silicon atoms and a methyl group or another organic group. What has been known is biochemical processes that result in break- ing such bonds [31]. Susceptibility of VMS to hydrolysis and biodegradation has been discussed in the literature. Still, in the 1970s they were considered to be nonbiodegradable compounds. The possibility of chemical decomposition and biodegradation of PDMS in contact with the soil has been demonstrated fairly recently [32-35]. The first stage includes decomposition of PDMS to siloxanes (mainly D4 and D5) and silanediols (mainly dimethylsilanediol - DMSD) by hydrolysis. Then, in anaerobic conditions, DMSD is subject to biodegradation in the soil, or is released into the air, where its photolytic decomposition occurs. In both cases, the end products are $\mathrm{CO}_{2}, \mathrm{SiO}_{2}$, and $\mathrm{H}_{2} \mathrm{O}$. PDMS may also undergo biodegradation in aerobic conditions [14, 36, 37]. However, these are very slow processes. For example, half-decomposition time of D5 in aerobic conditions exceeds 1,000 days [18].

\section{Effects of Silicones and Siloxanes on Living Organisms}

The toxicity of silicone compounds, in particular PDMS, has been thoroughly investigated due to their widespread use in medical technology and cosmetics. A lot of test results have indicated that these polymers are neutral to warmblooded organisms. Until recently, individual siloxanes were also believed to be non-toxic. However, studies carried out in recent years have shown that some of them may directly or indirectly affect the human body. The greatest number of data have been published on the toxicity of D4, which puts people at risk primarily due to the use of cosmetic products. It is considered to have toxic effects on reproductive processes [38-41], as well as the liver and lungs [42]. The effect of D4 on the estrous cycle of rats and mice also has been found [18, 43, 44]. According to the Regulation of the European Parliament and of the Council (EC) No. 1272/2008 of 16 December 2008 on the classification, labeling, and packaging of substances and mixtures, D4 exhibits a harmful effect on reproductivity (Cat. 2, R62 - possible risk of impaired fertility), and chronic aquatic toxicity (Cat. 4, R53 - may cause long-term, adverse changes in the aquatic environment). The Danish Environmental Protection Agency recognized reduction in fertility as a critical effect of D4 [45]. Assessing D4 toxicity from a lethal dose of $\mathrm{LD}_{50}$ for mice (6-7 $\mathrm{g} / \mathrm{kg}$ [46]), it can be concluded that it is similar to carbon tetrachloride or trichlorethylene.

D5 toxicity also has been studied. Like D4, D5 is a substrate in the production of PDMS used also in dry cleaning as a more secure replacement of perchlorethylene and trichlorethylene. No toxic effects of this siloxane on reproductive processes have been found [43, 44], but in 2005 the US EPA presented the results of research [47] which may confirm its carcinogenic effect. The study was conducted on 120 individuals in a population of laboratory rats exposed to D5 with vapor concentrations of $0,10,40$, and $160 \mathrm{ppm}_{\mathrm{v}} 6$ hours per day, 5 days per week, for 24 months. The results showed increased incidence of uterine cancer among the individuals exposed to concentrations of 160 
$\mathrm{ppm}_{\mathrm{v}}$. No increased incidence at lower doses of D5 was observed. In addition to the reproductive system, the organs most vulnerable to the effects of D4 and D5 are the lungs and liver. According to the above-mentioned regulation (EC) and Directive 67/548/EEC, D5 is not classified as a dangerous substance. However, in many publications it is claimed that the toxicological properties of D4 and D5 have not been thoroughly investigated.

The toxic properties of D6 also have been poorly researched. Due to larger sizes of D5 and D6 molecules in relation to D4 and, therefore, more difficult penetration through cell membranes, it may be suspected that their toxicity is relatively lower. Like D5, D6 has not been classified as a dangerous substance. There is also no specific data on the toxicity of linear VMS.

L2, for example, has been recognized as a skin irritant. Due to possible carcinogenic and toxic effects, in 2000 it was put on the OSPAR list of Chemicals for Priority Action. However, in a report [48] L2 was not classified as dangerous because research had not confirmed its toxic or carcinogenic properties. According to Regulation (EC) No. 1272/2008 and EU Directives 67/548/EEC and 1999/45/EC, this substance is toxic to aquatic organisms.

On the other hand, L5 was classified as a substance irritant to the skin, respiratory tract, and eyes. Although potential for adverse carcinogenic and/or toxic effects of D4 (liver and female reproductive system), D5, L2, and L5 (lungs, eyes, skin) has been found, the European Silicones Centre (CES) recognizes siloxane-based substances as completely safe for human health. Also, in the opinion of the Scientific Committee on Consumer Safety of the European Commission [49], cyclomethicone used in cosmetics poses no risk to human health. The opinion does not apply to other uses of the substance.

So far, there have been no restrictions or legal regulations on the use of siloxanes. Recently, however, the merits of such a policy have increasingly been questioned, especially in the case of cyclic VMS. Due to the great scale of production, a relatively long lifetime, and potential toxicity and bioaccumulation, it is considered to put some restrictions on some siloxanes. Currently, the risk assessment of cyclic VMS is being conducted, e.g. in Canada [19], in the EU [24], and in the USA [23], where D4 has recently been included by the U.S. EPA on the list of 18 substances that require risk assessment [50], which can provide the basis for the introduction of acceptable standards for that substance in the air. Further research into the effects of submicron silica emitted from the combustion of biogas on human health is also required. $\mathrm{SiO}_{2}$ particles are smaller than $100 \mathrm{~nm}$, and have big specific surface area and a fibrous form. They penetrate into the human body primarily through the respiratory passages and are transported into the circulatory system, spleen, liver and other organs, where they are further accumulated, so their negative impact on health can be spread over time. According to the classification of the British Standards Institution, silica dust has carcinogenic and mutagenic properties and can induce asthma and affect the reproductive system [51].

\section{Conclusions}

The increasing use of siloxanes, particularly cyclic VMS, in consumer and industrial products leads to their more common presence in the environment. Being highly volatile, they can easily get into the air, where they stay relatively long - from 2 (D6) to 30 (D3) days. Lifetimes of D5 and $\mathrm{D} 4$, which are emitted in the largest quantities, are from 7.5 to 12 days. Such a long decomposition time enables their transport across thousands of kilometers. They have been found, e.g., in the Arctic, although their only source is anthropogenic activity. Because of the poor water solubility and low reactivity, the only mechanism of removing VMS from the atmosphere is oxidation to silanols using hydroxyl radicals. Silanols, as better soluble in water, are removed by wet deposition and get into the soil, where they undergo slow microbial hydrolysis.

VMS reach the highest concentrations in the air (from a few to several $\mu \mathrm{g} / \mathrm{m}^{3}$ ) in the centers of large cities and near WWTPs, especially near the aeration tanks. The concentrations of cyclic VMS in air are 2-3 orders higher than those of linear. Especially low concentrations of linear VMS have been found in measuring points of the background and arctic areas, which indicates the short lifetime of these compounds in the atmosphere - as opposed to D3 and D4. Among cyclic VMS D5 and D4 are predominant. The ratio of their concentration in the air (such as, e.g., 4.5-2.1, according to research carried out in the USA), in connection with the difference in their lifetime, decreases with the distance from population centers, i.e. the places of intensive use of personal hygiene products, which use mainly D5.

Until recently, it was commonly believed that siloxanes are indifferent to human health. Today, more and more often it is claimed that they may be directly or indirectly toxic to various organs. These compounds are relatively persistent, with high potential for bioaccumulation. Some of them are suspected of carcinogenic potential (D5), harmful effects on the female reproductive system, the liver and lungs (D4), and the irritating effect on the skin, eyes and respiratory system (L2). So far, however, no legislation related to the use of siloxanes has been introduced - they are not covered by the restrictions on VOC, and there is no limit on concentrations acceptable in indoor and ambient air. Therefore, no control is performed and the published measurement results of VMS emission and immission are scarce. Still, in a few countries (the USA, Canada, the EU) risk assessment procedures have been recently launched, which may lead to the introduction of new regulations in the above-mentioned range. The lack of data on the toxicity of silanols resulting from the decomposition of siloxanes in the air also is noteworthy. Further research is also required for harmful effects of fine-crystalline silica resulting from siloxane combustion. Due to the size of emitted particles $(<100 \mathrm{~nm})$, it may be suspected that they can be easily inhaled into the lungs and the bloodstream. An additional negative aspect of the siloxane-containing biogas combustion is the deposition of silica on the engine components and active surfaces of 
exhaust gas catalysts, which indirectly increases emissions of other air pollutants.

The increasing introduction of products containing siloxanes to the consumers market - despite confirmation of the toxic effect of D4, D5, and L2 on rats and mice, no recognition of the toxicity of D3, L3, and L4 and silanols, and the confirmed ability of siloxanes to bioaccumulate in living organisms - requires the analysis of the situation by relevant decision-making bodies. It seems appropriate to make preventive arrangements to reduce people's exposure to their effects. The easiest way is to popularize the use of less harmful siloxane substitutes, particularly in the production of implants and cosmetics and in food industry (e.g., paraffin oils and glycols). Reducing VMS emissions can also be achieved by removing them from wastewater and sludge (e.g. oxidation in the aqueous phase) and biogas. The most commonly used method for VMS removal from biogas is adsorption on a fixed bed of activated carbon, removing them together with hydrogen sulfide and halides. Due to the limited capacity of sorbent regeneration and diverse sorption capacity in relation to different VMS, this method is not recommendable. Among the more promising adsorbents there are: alumina, ion-exchange resins and zeolites. In the preliminary stage of research there are absorption methods using organic liquids, membrane, catalytic, and biological methods.

The issues addressed in this paper are relatively new and poorly researched, especially in the context of toxicity and biodegradability of VMS, as well as the methods of their determination (there are no standard procedures) and removal from biogas and sewage.

\section{References}

1. The 2007 OECD List of High Production Volume Chemicals, OECD Environment, Health and Safety Publications, Series on Testing and Assessment. No. 112, ENV/JM/MONO(2009)40, Paris, 2009.

2. GAJ K., CIOŁEK J., PAKULUK A., STEININGER M. Siloxanes in biogas - origin, hazards and analytical problems, GWiTS, 4, 394, 2014 [In Polish].

3. APPELS L., BAEYENS J., DEWIL R. Siloxane removal from biosolids by peroxidation. Energy Conversion and Management, 49, (10), 2859, 2008.

4. KAZUYUKI O., MASAKI T., TADAO M., HIROSHI K., NOBUO T., AKIRA K. Behavior of siloxanes in a municipal sewage-treatment plant. J. Jpn. Sewage Works Ass. 44, (531), 125, 2007.

5. ARNOLD M., KAJOLINNA T. Development of on-line measurement techniques for siloxanes and other trace compounds in biogas, Waste Manage., 30, (6), 1011, 2010.

6. TOWER P. New technology for removal of siloxanes in digester gas results in lower maintenance costs and air quality benefits in power generation equipment. WEFTEC 03$78^{\text {th }}$ Annual Technical Exhibition and Conference, October, 2003.

7. MULLER J.A., DI TORO D.M., MAIELLO J.A. Fate of octamethylcyclotetrasiloxane (OMCTS) in the atmosphere and in sewage treatment plants as an estimation of aquatic exposure. Environ. Toxicol. Chem., 14, (10), 1657, 1995.
8. ALLEN R.B., KOCHS P., CHANDRA G. Industrial organic materials, their environmental entry and predicted fate in organosilicon materials. HUTZINFER O. Handbook of Environmental Chemistry. Berlin: Springer-Verlag, 1-25, 1997.

9. RASI S., LEHTINEN J., RINTALA J. Determination of organic silicon compounds in biogas from wastewater treatments plants, landfills, and co-digestion plants. Renew. Energ., 35, (12), 2666, 2010.

10. APPELS L., BAEYENS J., DEGRE'VE J., DEWIL R. Principles and potential of the anaerobic digestion of wasteactivated sludge. Prog. Energ. Combust. 34, (6), 755, 2008.

11. DEUBLEIN D., STEINHAUSER A. (Eds.). Biogas from waste and renewable resources. WILEY-VCH, Weinheim, 2008.

12. LIANG K.Y., LI R., SHEEHAN J.F. Removing siloxanes: solution to combustion equipment problems. Proceedings of the Water Environment Federation. WEFTEC, Session 1120, 303, 2002.

13. EPRI. Assessment of Fuel Gas Cleanup Systems for Waste Gas Fueled Power Generation. Electric Power Research Institute. 1012763, Technical Update, California, 2006.

14. ACCETTOLA F., HABERBAUER M. Control of siloxanes in: Lens P., Westermann P., Habebauer M., Moreno A. (Eds.), Biofuels for Fuel Cells, Renewable energy from biomass fermentation. IWA Publishing, London, 445, 2005.

15. SCHWEIGKOFLER M., NIESSNER R. Removal of siloxanes in biogases. J. Hazard. Mater., 83, (3), 183, 2001.

16. WHELESS E., PIERCE J. Siloxanes in landfill and digester gas update. SWANA $27^{\text {th }}$ LFG Conference, SCS Energy, San Antonio, California, 2004.

17. ARNOLD M. Reduction and monitoring of biogas trace compounds. VTT TIEDOTTEITA - Research Notes 2496, VTT Technical Research Centre of Finland, 2009.

18. WANG D.G., NORWOOD W., ALAEE M., BYER J.D., BRIMBLE S. Review of recent advances in research on the toxicity, detection, occurrence and fate of cyclic volatile methyl siloxanes in the environment. Chemosphere 93, (5), 711, 2013.

19. GENUALDI S., HARNER T., CHENG Y., MACLEOD M., HANSEN K.M., VAN EGMOND R., SHOEIB M., LEE S.C. Global distribution of linear and cyclic volatile methyl siloxanes in air. Environ. Sci. Technol. 45, (8), 3349, 2011.

20. KAJ L., SCHLABACH M., ANDERSSON J., PALM A.P., SCHMIDBAUER N., BRORSTRÖM-LUNDÉN E. Siloxanes in the Nordic Environment. Norden, TemaNord, 593, Nordic Council of Ministers. Copenhagen, 2005.

21. KAJ L., ANDERSSON J., COUSINS A.P., REMBERGER M., BRORSTRÖM-LUNDÉN E., CATO I. Results from the Swedish National Screening Programme 2004. Subreport 4: Siloxanes. IVL Swedish Environmental Research Institute Ltd., IVL report B1643, Stockholm, 2005.

22. CHENG Y., SHOEIB M., AHRENS L., HARNER T., MA J. Wastewater treatment plants and landfills emit volatile methyl siloxanes (VMSs) to the atmosphere: Investigations using a new passive air sampler. Environ. Pollut. 159, (10), 2380, 2011.

23. YUCUIS R.A., STANIER C.O, KERI C., HORNBUCKLE K.C. Cyclic siloxanes in air, including identification of high levels in Chicago and distinct diurnal variation. Chemosphere 92, (8), 905, 2013.

24. MCLACHLAN M.S., KIERKEGAARD A., HANSEN K.M., VAN EGMOND R., CHRISTENSEN J.H., SKJOTH C.A. Concentrations and fate of decamethylcyclopentasiloxane (D5) in the atmosphere. Environ. Sci. Technol. 44, (14), 5365, 2010. 
25. BUSER A.M., KIERKEGAARD A., BOGDAL C., MACLEOD M., SCHERINGER M., HUNGENBÜHLER $\mathrm{K}$. Concentrations in ambient air and emissions of cyclic volatile methylsiloxanes in Zurich, Switzerland. Environ. Sci. Technol. 47, (13), 7045, 2013.

26. HOBSON J.E., ATKINSON R., CARTER W.P.L. Volatile methylsiloxanes. in organosilicon materials, Hutzinegr, O. (red.), Handbook of Environmental Chemistry, Berlin: Springer-Verlag, 1-25, 1997.

27. ATKINSON R. Kinetics of the gas-phase reactions of a series of organosilicon compounds with $\mathrm{OH}$ and $\mathrm{NO}_{3}$ radicals and $\mathrm{O}_{3}$ at $297 \pm 2 \mathrm{~K}$. Environ. Sci. Technol. 25, (5), 863, 1991.

28. NAVEA J.G., YOUNG M.A., XU S., GRASSIAN V.Ch., STANIER Ch.O. The atmospheric lifetimes and concentrations of cyclic methylsiloxanes octamethylcyclotetra-siloxane (D4) and decamethylcyclopentasiloxane (D5) and the influence of heterogeneous uptake. Atmos. Environ. 45, (18), 3181, 2011.

29. MACLEOD M., KIERKEGAARD A., GENUALDI S., HARNER T., SCHERINGER M. Junge relationships in measurement data for cyclic siloxanes in air. Chemosphere 93, (5), 830, 2013.

30. HOWARD P.H., MUIR D.C.G. Identifying new persistent and bioaccumulative organics among chemicals in commerce. Environ. Sci. Technol. 44, (7), 2277, 2010.

31. DEWIL R., APPELS L., BAEYENS J. Energy use of biogas hampered by the presence of siloxanes. Energ. Convers. Manage. 47, (13-14), 1711, 2006.

32. GRUMPING R., MICHALKE K., HIRNER A.V., HENSEL R. Microbial degradation of octamethylcyclotetrasiloxane (D4). Appl. Environ. Microb. 65, (5), 2276, 1999.

33. GRIESSBACH E.F.C., LEHMANN R.G. Degradation of polydimethylsiloxane fluids in the environment - a review. Chemosphere 38, (6), 1461, 1999.

34. OHANNESSIAN A., DESJARDIN V., CHATAIN V., GERMAIN P. Volatile organic silicon compounds: the most undesirable contaminants in biogases. Water Sci. Technol. 58, (9), 1775, 2008.

35. BROOKE D.N., CROOKES M.J., GRAY D., ROBERTSON S. Environmental Risk Assessment Report: Decamethylcyclopentasiloxane. UK Environment Agency, Rio House, Waterside Drive, Aztec West, Almondsbury, Bristol, 2009.

36. ACCETTOLA F., GUEBITZ G.M., SCHOEFTNER R. Siloxane removal from biogas by biofiltration: biodegradation studies. Clean Techn. Environ. Policy 10, (2), 211, 2008.

37. WASSERBAUER R., ZADAK Z. Growth of Pseudomonas putida and P. fluorescens on silicone oils. Folia Microbiol. 35, (5), 384, 1990

38. MEEKS R.G., STUMP D.G., SIDDIQUI W.H., HOLSON J.F., PLOTZKE K.P., REYNOLDS V. L. An inhalation reproductive toxicity study of octamethylcyclotetra-siloxane (D4) in female rats using multiple and single day exposure regimens. Reprod. Toxicol. 23, (2), 192, 2007

39. QUINN A.L., DALU A., MEEKER L.S., JEAN P.A., MEEKS R.G., CRISSMAN J.W., GALLAVAN Jr R.H.,
PLOTZKE K.P. Effects of octamethylcyclotetrasiloxane (D4) on the luteinizing hormone (LH) surge and levels of various reproductive hormones in female Sprague-Dawley rats. Reprod. Toxicol., 23, (4), 532, 2007.

40. SIDDIQUI W.H., STUMP D.G., PLOTZKE K.P., HOLSON J.F., MEEKS R.G. A two-generation reproductive toxicity study of octamethylcyclotetrasiloxane (D4) in rats exposed by whole-body vapor inhalation. Reprod. Toxicol. 23, (2), 202, 2007.

41. MCKIM J.M. Jr, WILGA P.C., BRESLIN W.J., PLOTZKE K.P., GALLAVAN R.H., MEEKS R.G. Potential estrogenic and antiestrogenic activity of the cyclic siloxane octamethylcyclotetra-siloxane (D4) and the linear siloxane hexamethyldisiloxane (HMDS) in immature rats using the uterotrophic assay. Toxicol. Sci. 63, (1), 37-46, 2001.

42. MCKIM J.M. Jr, CHOUDHURI S., WILGA P.C., MADAN A., BURNS-NAAS L.A., GALLAVAN R.H., MAST R.W., NAAS D.J., PARKINSON A., MEEKS R.G. Induction of hepatic xenobiotic metabolizing enzymes in female Fischer344 rats following repeated inhalation exposure to decamethylcyclopentasiloxane. Toxicol. Sci. 50, (1), 10, 1999.

43. QUINN A.L., REGAN J.M., TOBIN J.M., MARINIK B.J., MCMAHON J.M., MCNETT D.A., SUSHYNSKI Ch.M., CROFOOT S.D., JEAN P.A, PLOTZKE K.P. In vitro and in vivo evaluation of the estrogenic, androgenic, and progestagenic potential of two cyclic siloxanes. Toxicol. Sci., 96, (1), 145, 2007.

44. HE B., RHODES-BROWER S., MILLER M.R., MUNSON A.E., GERMOLEC D.R., WALKER V.R., KORACH K.S., MEADE B.J. Octamethylcyclotetrasiloxane exhibits estrogenic activity in mice via ER $\alpha$. Toxicol. Appl. Pharm. 192, (3), 254, 2003.

45. LASSEN C., HANSEN Ch.L., MIKKELSEN S.H., MAAG J. Siloxanes - consumption. Toxicity and Alternatives. Environmental Project No. 1031, Miljøprojekt, Danish Environmental Protection Agency, 2005.

46. LIEBERMAN M.W., LYKISSA E.D., BARRIOS R., OU Ch.N, KALA G., KALA S.V. Cyclosiloxanes produce fatal liver and lung damage in mice. Environ. Health Persp. 107, (2), 161, 1999.

47. EPA. Siloxane D5 in drycleaning application. Fact Sheet, Office of Pollution Prevention and Toxics (7404) US EPA, 2009.

48. OSPAR background document on hexamethyldisiloxane. Hazardous Substances Series No. 201, OSPAR Commission, London, 2004.

49. European Commission. Directorate-General for Health\&Consumers, Scientific Committee on Consumer Safety, Opinion on cyclomethicone (D4/D5), SCCS/1241/10, 2010.

50. EPA. Work Plan Chemicals for Assessment During 2013 and 2014 - Targets 18 chemicals for review, 2012, http://www.epa.gov/oppt/existingchemicals/pubs/workplanlist.html.

51. BSI. Nanotechnologies - Part 2: Guide to safe handling and disposal of manufactured nanomaterials, PD 6699-2-2007. British Standards Institution. London, 2007. 
